\title{
Korupsi Sebagai Suatu Bentuk White Collar Crime
}

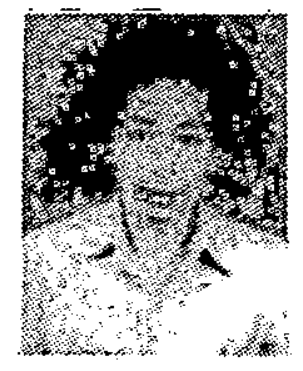

Rusli Muhammad

Korupsi, baik dalam proses maupun efeknya ternyata telah melahirkan berbagai masalah problematis dan krusiah, terlebih jenis korupsi yang masuk klasifikasi WCC, demikian terungkap dari uraian ekstensif-nya Rusli Muhammad berikut ini.

\section{Pendahuluan}

SEORANG kriminolog bernama Edwin $\mathrm{H}$. Sutherland yang pertama kali menyebut istilah "white collar crime" dalam pidatonya di depan American Sociological Sociaty pada tahun 1930. Beliau merumuskannya sebagai kejahatan yang dilakukan oleh orang-orang yang memiliki kedudukan sosial yang tinggi dan terhormat dalam pekerjaannya (crime committed by person of respectability and high social status in the course of their occupation) ${ }^{2}$

Melihat perumusan konsep "white collar crime" tersebut maka dapat dipahami bahwa Sutherland ingin untuk merombak teori tentang perilaku kriminal yang secara tradisional sudah stereotip yang menyatakan bahwa, pelaku kejahatan adalah orang-orang yang berasal dari kelas-kelas sosial dan ekonomi yang rendah. Sehingga tidaklah mengherankan kalau - kemudian timbul ungkapan bahwa ${ }^{2}$ "air tidak pernah mengalir ke atas" untuk penerapan hukum pidana. Dengan kata lain, air selalu mengalir ke bawah; artinya: hukum pidana -- ibarat -- selalu "menerkam" rakyat lapisan bawah. Mereka inilah termasuk golongan miskin yang selalu menjadi obyek hukum pidana karena dianggap sebagai pelaku tetap dari kejahatan seperti, perampokan, pencurian dan kejahatan-kejahatan kekerasan lainnya.

Dengan demikian maka gagasan Sutherland dalam "white collar crime" itu ingin menunjukkan bahwa, pelaku kejahatan dan kajahatannya itu sendiri tidak hanya sekedar dilakukan dan berada di kalangan masyarakat yang rendah atau golongan miskin, melainkan dapat ditemukan juga dalam kelas-kelas masyarakat yang lebih tinggi, yakni mereka yang dalam penampilan sehari-harinya selalu berdasi, bermobil mewah, berpakaian necis dan berparfum menawan.

Apa yang menjadi perhatian Sutherland dalam konsep "white collar crime" dengan menempatkan golongan elite sebagai pelaku kejahatan tidak lain untuk menegaskan tun- 
tutannya berupa keadilan yang sama derajatnya (equal justice) dalam sistem penyelenggaraan hukum pidana. Artinya hukum pidana selain dapat menerkam golongan miskin dapat pula menjangkau dan menerkam golongan. masyarakat elite.

Gagasan "white collar crime" kemudian berkembang menuju cakrawala yang lebih luas sehingga konsep ini dapat digunakan dalam berbagai peristilahan dan pemaknaan dari berbagai macam jenis-jenis kejahatan seperti kejahatan jabatan dan kejahatan ekonomi, kejahatan korporasi dan sebagainya. Korupsi adalah merupakan salah satu bentuk konkrit dari "white collar crime" itu.

Tulisan ini tidak akan panjang lebar membahas "white collar crime" dalam bentuk konsep dan perkembangannya, tetapi lebih memprioritaskan pembahasan pada salah satu bentuk kongkrit kejahatan "white collar crime", yakni "korupsi". Pembahasan terhadap korupsi meliputi: Bahaya-bahaya Korupsi, Rumusan Delik Korupsi, Kasus-kasus Korupsi Kerah Putih, Sebab-sebab Terjadinya dan Alternatif Pencegahannya.

\section{Bahaya-bahaya Korupsi}

PEMBICARAAN terhadap korupsi tidak akan berakhir dan akan berlangsung terus sepanjang masih ada yang ingin dan melakukan terhadap penyakit yang satu ini. Mestinya harus demikian, sebab kalau sudah muncul kebosanan apalagi berhenti membicarakan korupsi yang semakin memperlihatkan peningkatan kualitas dan kuantitasnya, berarti secara langsung maupun tidak langsung kita telah ikut serta membiarkan dan melestarikan perbuatan pidana korupsi.

Belakangan ini masalah korupsi kembali mencuat, terutama setelah munculnya kasus pembobolan keuangan BAPINDO oleh Eddy Tansil yang sekarang ini kasusnya sedang Jalam proses peradilan. Kasus ini sungguh menarik karena selain melibatkan para pimpinan Bank, disinyalir pula melibatkan beberapa petinggi negara. Dan lebih hebat lagi kasus ini mempunyai rekor tertinggi dalam hal jumlah kerugian yang diderita oleh negara.
Kasus ini adalah satu peringatan serius bahwa korupsi di negeri ini sudah memperlihatkan kualitas yang sungguh membahayakan.

Kualitas korupsi yang demikian itu sungguh menakutkan dan sangat berbabaya tidak saja bagi negara tapi juga. kepada rakyatnya. Keutuhan pemerintahan akan terancam dan tidak menutup kemungkinan akan meruntuhkan kekuasaan pemerintahan. Pelajaran dari negaranegara lain seperti Pilipina, Thailand, Afrika, Jepang bahkan Amerika Serikat pernah terguling pemerintahannya akibat merajalelanya korupsi di negaranya. Di kalangan masyarakat, hubungan-hubungan sosial menjadi tegang, timbul kecemburuan di kalangan penduduk dan pada gilirannya merangsang munculnya kejahatan lain. Akhirnya stabilitas, keamanan dan ketertiban akan terbengkalai, negarapun akan hancur!

Kita telah mengetahui bahwa korupsi adalah suatu gejala penyakit sosial/masyarakat dan akan menjelma menjadi penyakit bila tidak segera diadakan tindakan pencegahan. Di samping itu korupsi adalah perbuatan yang merusak, melanggar, menyuap, menggoda yang di samping bertentangan dengan pandangan masyarakat dan lebih-lebih bertentangan dengan undang-undang.

Terkadang korupsi membayangkan perbuatan yang hina, merusak moral dan apabila korupsi ini. telah menjalar kepada pegawai negeri, para pejabat dan penguasa negara, maka korupsi itu jelas berbahaya karena akan menciptakan ketidak-percayaan lagi terhadap aparat pemerintah, masyarakat akan menjauhkan diri dari pemerintah. Pimpinan pemerintahan, aparatur negara akan kehilangan wibawa mereka. Berkaitan dengan itu pula, Muchtar Lubis dalam bukunya menyebutkan bahwa:

"Sikap sinisme akan menjalar luas, juga di kalangan pejabat sendiri dan terutama sekali di kalangan masyarakat, yang merusak segala disiplin kerja, rasa tanggung-jawab jabatan, sikap pengabdian pejabat terhadap kepentingan rakyat dan negara serta bangsa, dan di kalangan masyarakat timbul rasa 
tidak puas dan keresahan yang sangat, karena merasa bahwa mereka diperlakukan sebagai sasaran pemerasan belaka oleh penguasa negara mereka. ${ }^{3}$

Semua itu merusak nilai-nilai dan solidaritas masyarakat, akhirnya tiada lagi orang yang dapat membedakan antara yang baik dan yang buruk, antara yang benar dan yang tidak benar, akibatnya melemahkan apa yang disebut-sebut "the rule of law" sendiri. Berkaitan pula dengan itu suatu pernyataan di Harian Kompas beberapa puluh tahun yang lalu menyebutkan bahwa sebagai akibat meluasnya korupsi ialah: berkembangnya kriminalitas dalam masyarakat, sedang efisiensi serta integritas negara tercampakkan. Selain itu generasi muda akan tumbuh dalam suasana yang berlatar-belakang negatif. Mereka tidak tahu tentang cara maju di dunia, kecuali dengan cara penyuapan atau tipu-daya lainnya. ${ }^{4}$

Kita memang tidak menghendaki munculnya korupsi dalam segala bentuknya, namun sampai sekarang pula kita tidak kuasa menghindarinya, ternyata korupsi masih ada dan di mana-mana. Pengadilan pun di mana-mana sibuk mengadili para pelakunya. Sebenarnya usaha untuk menangkal dan mencari sumber akar terjadinya korupsi telah lama dilakukan bahkan sudah sekian banyak sarjana dari berbagai disiplin ilmu ikut serta dan diikut-sertakan oleh pemerintah dalam usaha untuk memecahkan dan mencari sumber-sumber korupsi. Anjuran supaya berlaku jujur, supaya orang memperbaiki akhlak, hidup sederhana, tingkatkan pengawasan melekat dan lain sebagainya telah sering kita dengar, tapi mengapa korupsi tetap saja menggerogoti keuangan dan perekonomian negara ini? Suatú pertanyaan yang meskipun jawabannya telah banyak diberikan, namun belum juga meredam dan mencegah lajunya kejahatan korupsi.

\section{Delik (Tindak Pidana) Korupsi}

SEJAK Kemerdekaan Republik Indonesia baru terdapat 2 (dua) undang-undang yang mengatur delik korupsi, sebelumnya hanya diatur dalam Peraturan Pemerintah Pengganti
Undang-undang. Kedua Undang-undang tersebut adalah Undang-undang Nomor 24 Prp. Tahun 1960 tentang Pengusutan Penuntutan dan Pemeriksaan Tindak Pidana Korupsi dan Undang-undang Nomor 3 Tahun 1971 tentang Undang- undang Pemberantasan Tindak Pidana Korupsi. Undang-undang yang disebut pertama sudah dinyatakan tidak berlaku lagi dengan dikeluarkannya Undang-undang yang kedua. Meskipun demikian sekedar pembanding dicoba dikemukakan di bawah ini.

Undang-undang Nomor 24 Prp. Tahun 1960 sebagaimana terdapat dalam Pasal 1 menerangkan bahwa yang disebut tindak pidana korupsi ialah:

a. Tindakan seseorang yang dengan atau karena melakukan suatu kejahatan atau pelanggaran memperkaya diri sendiri atau orang lain atau suatu badan yang secara langsung atau tidak langsung merugikan keuangan negara atau perekonomian negara atau daerah atau badan hukum lain yang mempergunakan modal dan kelonggarankelonggaran dari negara atau masyarakat.

b. Perbuatan seseorang yang dengan atau karena melakukan suatu kejahatan atau pelanggaran memperkaya diri sendiri atau orang lain atau badan dan yang dilakukan dengan menyalahgunakan jabatan atau kedudukan.

c. Kejahatan yang tercantum dalam pasal 17 sampai 21 peraturan ini dan dalam pasal 209 , $210,415,416,417,418,419,420,423,425$, dan 435 Kitab Undang-undang Hukum Pidana.

Rumusan delik korupsi ini nampaknya berbeda dengan perumusan delik korupsi yang terdapat di dalam Undang-undang Nomor 3 Tahun 1971. Rumusan delik dalam Undangundang ini berusaha untuk mengubah dan memperluas rumusan delik tersebut di atas yang dianggap sudah ketinggalan dan sudah tidak memenuhi tuntutan zaman.

Perumusan delik korupsi menurut Undangundang Nomor 3 Tahun 1971 disebutkan dalam pasal 1 yang mengatakan bahwa dihukum karena tindak pidana korupsi ialah:

(1) a. 
Barangsiapa dengan melawan hukum melakukan perbuatan memperkaya diri sendiri atau orang lain, atau suatu badan, yang secara langsung atau tidak - langsung merugikan keuangan negara atau perekonomian negara;

b. Barangsiapa dengan tujuan menguntungkan diri sendiri atau orang lain atau suatu badan, menyalah-gunakan kewenangan, kesempatan atau sarana yang ada padanya karena jabatan atau kedudukan, yang secara langsung atau tidak langsung dapat merugikan keuangan negara atau perekonomian negara;

c. Barangsiapa melakukan kejahatan tercantum dalam Pasal 209, 210, 387, $388,415,416,417,418,419,420,425$ dan 435 KUHP;

d. Barangsiapa memberi hadiah atau janji kepada pegawai negeri seperti dimaksud dalam Pasal 2 dengan mengingat suatu kekuasaan atau wewenang yang melekat pada jabatan atau kedudukannya atau oleh si pemberi hadiah atau janji dianggap melekat pada jabatan atau kedu- dukan itu;

e. Barangsiapa tanpa alasan yang wajar, dalam waktu sesingkat-singkatnya telah menerima pemberian atau janji yang diberikan kepadanya, seperti tersebut dalam pasal 418,419 , dan 420 KUHP tidak melapor pemberian atau janji tersebut kepada yang berwajib;

(2) Barangsiapa melakukan percobaan atau permufakatan untuk tindak pidana-tindak pidana tersebut dalam ayat (1) a, b, c, d, e pasal ini.

Dengan demikian, ternyata bahwa rumusan delik pada Undang-undang Nomor 3 Tahun 1971 lebih luas dibandingkan dengan rumusan delik pada Undang-undang Nomor 24 Prp. Tahun 1960, sebab dalam Undang-undang Nomor 3 Tahun 1971 menyebutkan unsur "melawan hukum", dimulai dengan kata "barangsiapa", tidak mensyaratkan adanya kejahatan atau pelanggaran, adanya tambahan pasal 387 dan 388 KUHP, tambahan ayat d dan e, dan adanya ayat 2 tentang percobaan dan permufakatan.

Adanya unsur "melawan hukum" dalam delik korupsi itu dimaksudkan untuk menggantikan unsur "Kejahatan dan Pelanggaran" yang terdapat dalam rumusan delik sebelumnya. Penggantian tersebut dengan sendirinya semakin memudahkan jaksa membuktikan tentang perbuatan yang dapat dihukum di sidang pengadilan karena tidak perlu lagi bersusah payah membuktikan terlebih dahulu adanya kejahatan atau pelanggaran. Demikian pula ruang gerak daripada perbuatan yang dapat dipidana itu lebih luas, karena tidak lagi sekedar terikat oleh kejahatan dan pelanggaran yang terlebih dahulu harus dirumuskan dalam Undang-undang, tanpa itu asalkan sifatnya memenuhi unsur melawan hukum, perbuatan tersebut sudah dapat diajukan ke depan sidang pengadilan.

Unsur "melawan hukum" tersebut sebagaimana disebutkan dalam Penjelasan Umum Undang-undang Nomor 3 Tahun 1971 adalah mengandung pengertian Formil maupun Materiil. Sifat melawan hukum materiil mempunyai fungsi yang negatif dan fungsi yang positif. Karena penjelasan umum tersebut tidak membatasi fungsi dari melawan hukum materiil itu, berarti keduanya dapat diperlakukan baik fungsi yang negatif maupun fungsi yang positif. Ketentuan Pasal 1 ayat 1 KUHP yang mengandung azas legalitas dengan sendirinya tidak bermakna bagi delik-delik korupsi, sebab sifat melawan hukum materiil (materiele wederrechtelijkheid) dalam fungsi yang positif membatasi berlakunya azas legalitas tersebut.

Adapun fungsi yang positif dari sifat melawan hukum itu dijelaskan oleh Prof. Moeljatno, yaitu perbuatan tidak dilarang oleh undang-undang, tetapi oleh masyarakat perbuatan itu dianggap keliru ${ }^{5}$. Dapat dipahami bahwa meskipun suatu perbuatan belum diatur dalam undang-undang, namun perbuatan tersebut tetap dapat dituntut ke pengadilan 
asalkan masyarakat menganggap bahwa perbuatan tersebut adalah perbuatan yang keliru atau tidak patut. Berbeda dengan fungsi negatif dari sifat melawan hukum, justru mengecualikan perbuatan yang meskipun masih dalam perumusan undang-undang, namun tidak merupakan tindak pidana yang dapat diajukản ke pengadilan.

Kembali kepada delik korupsi dalam Undang-undang Nomor 3 Tahun 1971, menunjukkan bahwa terdapat beberapa perbuatan yang tadinya bukan merupakan delik korupsi menjadi delik korupsi, di samping itu beberapa pasal KUHP ditarik menjadi delik korupsi. Perbuatan yang dimaksudkan adalah perbuatan yang dirumuskan dalam Pasal 1 ayat 1 sub $\mathrm{d}$ sebagaimana telah disebutkan di atas. Dengan munculnya ketentuan ini berarti mereka yang memberikan hadiah atau janji kepada pegawai negeri dengan mengingat sesuatu kekuasaan atau wewenang yang melekat pada jabatannya digolongkan sebagai delik korupsi. Ketentuan ini hampir mirip dengan pasal 209 KUHP, bedanya terletak pada unsur "berlawanan dengan jabatannya", di mana pegawai negeri dalam pasal 209 harus melakukan atau mengalpakan sesuatu yang berlawanan dengan jabatannya, sementara dalam Pasal 1 ayat 1 sub d tidak mensyaratkan hal itu, bahkan tidak disyaratkan pula bahwa pegawai negeri ini menerima hadiah tersebut. Untuk memudahkan mendapatkan kredit yang diinginkan, seorang kreditur kemudian menjanjikan atau memberi hadiah berupa uang atau benda apa saja yang bernilai kepada pejabat yang berwenang mengeluarkan kredit tersebut, adalah merupakan contoh kongkrit dari delik korupsi berdasarkan Pasal 1 ayat 1 sub d di atas.

Delik korupsi lainnya yang baru muncul dalam Undang-undang Korupsi Nomor 3 Tahun 1971 adalah rumusan delik pada Pasal 1 ayat 1 sub e, yakni pegawai negeri yang tanpa alasan yang wajar, dalam waktu yang sesingkat-singkatnya setelah menerima pemberian atau janji yang diberikan kepadanya yang tersebut dalam Pasal 418, 419 dan 420 KUHP, tidak melaporkan pemberian atau janji tersebut kepada yang berwajib.
Jenis korupsi tersebut dapat dilukiskan sebagai berikut: seorang Hakim yang sedang memeriksa terdakwa dalam perkara pidana korupsi, suatu ketika didatangi oleh terdakwa dengan membawa hadiah atau janji. Hadiah atau janji ini diberikan kepada Hakim tersebut karena terdakwa tahu bahwa Hakim itulah yang mengadili perkaranya dan Hakim itu pun mengerti bahwa hadiah atau janji itu diberikannya karena jabatannya sebagai Hakim yang sedang memeriksa perkaranya. Karena hadiahnya atau janjinya cukup merangsang menyebabkan Sang Hakim tidak kuasa menolaknya. Hadiah atau janji pun diterimanya tanpa melaporkan kepada yang berwajib melainkan disimpannya bahkan dipergunakan sebagai miliknya.

\section{Kasus-Kasus Korupsi "Kerah Putih"}

SEBENARNYA istilah Korupsi Kerah Putih tidak dikenal dalam literatur, tidak ada pembagian bentuk-bentuk korupsi seperti itu, namun yang dimaksud dengan istilah tersebut adalah kejahatan korupsi yang dilakukan oleh kalangan atas, yang mempunyai status sosial dan kekayaan yang melebihi dari orang-orang kebanyakan. Oleh karena itu maka kasus-kasus yang akan dikemukakan berikut ini adalah kasus korupsi yang dilakukan oleh pejabat atau kalangan atas yang mempunyai status sosial dan ekonomi yang lebih mapan.

Kasus korupsi Kerah Putih jumlahnya cukup banyak bahkan tak terhitung lagi karena pada umumnya kejahatan korupsi dilakukan oleh orang-orang yang mempunyai status sosial dan ekonomi yang lebih mapan. Yang akan dikemukakan di sini hanyalah sekedar sampel terkecil dari keseluruhan kasus-kasus korupsi kerah putih. Pertama adalah, kasus korupsi atas nama terdakwa Tony, G. Alias G.T. Kasus ini telah mendapat putusan Pengadilan Negeri Ujung Pandang, Pengadilan Tinggi dan Mahkamah Agung. Posisi kasus ini sebagai berikut: Pada tahun 1977 sampai dengan tahun 1984 di Ujung Pandang telah menguasai/memiliki tanah seluas $7.707 \mathrm{~m}^{2}$ eks terminal bus pasar Sentral Makasar, sedangkan terdakwa hanya memperoleh pelepasan hak atas tanah seluas 
$5.700 \mathrm{~m}^{2}$ dari Walikota Ujung Pandang dan' kemudian terdakwa menunjuk batas yang salah sehingga seluas $7.150 \mathrm{~m}^{2}$ yang disertifikatkan ${ }^{6}$.

Serangkaian perbuatan yang dilakukan terdakwa yakni ketika dalam proses permohonan hak pakai terdakwa atas tanah eks Terminal Bus Pasar Sentral Ujung Pandang kepada Mendagri cq. Dirjen Agraria yang diperolehnya dari Pemda KMUP sebagai kompensasi pembangunan Terminal Bus Panaikang dan pengaturan Terminal Pa'baeng-baeng Ujung Pandang seluas $150 \times 38 \mathrm{~m}^{2}=5.700 \mathrm{~m}^{2}$ dengan perhitungan harga Rp $25.000,-/ \mathrm{m}^{2}$ sesuai Surat Keputusan Panitia Penjualan dan Pembelian rumah/tanah KMUP tanggal 9 Juli 1976 dan dokumen-dokumen sah lainnya, tetapi pada waktu terdakwa menunjukkan batas-batas tanag tersebut telah dengan sengaja menunjukkan batas yang lebih daripada yang tercantum dalam Surat Keputusan Panitia tersebut sehingga mencapai seluas $7.150 \mathrm{~m}^{2}$ dan selanjutnya terdakwa mencantumkan luas $7.150 \mathrm{~m}^{2}$ tersebut dalam permohonan hak pakai yang disampaikannya kepada Kantor Agrari KMUP. Selain perbuatan tersebut terdakwa memiliki pula yanpa hak atas tanah Pemda KMUP seluas $546 \mathrm{~m}^{2}$ disekeliling tanah tersebut.

Perbuatan terdakwa yang memperkaya diri sendiri secara melawan hukum tersebut telah menimbulkan kerugian Negara berupa tanah seluas $7.150 \mathrm{~m}^{2}-5.700 \mathrm{~m}^{2}=1.450 \mathrm{~m}^{2}$ dan ditambah $456 \mathrm{~m}^{2}$ atau seluruhnya berjumlah $1.906 \mathrm{~m}^{2}$ dengan taksiran harga sekarang $\mathrm{Rp}$ $5.000 .000,-/ \mathrm{m}^{2}$ atau seluruhnya bernilai $\mathrm{Rp}$ 953.000.000,- atau sekitar jumlah tersebut. Atas perbuatan yang dilakukan terdakwa tersebut kemudian Mahkamah Agung menjatuhkan pidana penjara selama 5 tahun dipotong masa tahanan.

Kasus korupsi kerah putih berikut ini tergolong kasus yang dulu pernah menjadi pembicaraan ramai karena cukup menggegerkan perbankan Indonesia, khususnya Bank Duta. Pelakunya adalah Dicky Iskandar $\mathrm{Di}$ Nata, ketika itu ia menjabat sebagai Dirut Bank Duta. Perkaranya sudah mendapat putusan Pengadilan Negeri yang ketika itu divonis selama 10 tahun dan membayar uang ganti $\mathrm{Rp}$ 811 milyar. Dick, naik banding dan kasasi, namun ternyata Mahkamah Agung menguatkan putusan Pengadilan Tinggi yang ketika itu menjatuhkan putusan selama 8 tahun penjara.

Menurut hakim ${ }^{7}$, Dicky nyata-nyata bersalah menyalah-gunakan wewenangnya sejak diangkat sebagai Wakil Direktur Utamà dan Direktur Eksekutif Bank Duta, 1989. Selain ditugasi mengelola sepenuhnya operasional Bank Duta sehari-hari ia diserahi mengawasi urusan treasury (perdagangan valas). Ternyata, Dicky malah ikut terjun sebagai dealer -seharusnya tidak boleh -- baik untuk posisi Bank Duta maupun untuk posisi nasabah Edwin Boy Adam. Padahal, para.dealer dalam kegiatannya diawasi oleh chief dealer, dan chief dealer berada di bawah pengawasan Dicky. Tentu saja chief dealer tidak bisa mengawasi Dicky ketika sang bos ikut terjun menjadi dealer.

Akibat dari tindakan Dicky sebagai dealer justru mengakibatkan lumbuhnya pengawasan di treasury Bank Duta. Kegiatan perdagangan valas menjadi tidak terkendali, sehingga para dealer melakukan transaksinya tanpa limit.

Lebih lanjut Hakim menyebutkan bahwa, masaiahnya bertambah parah ketika Dicky mengambil transaksi-transaksi besar untuk posisi Boy Adam maupun Bank Duta secara bersamaan: Tujuan Dicky adalah supaya posisi Bank Duta, yang dibuat chief dealer Risanto Sasmoyo, bisa ditutup. Tetapi ternyata pada Januari 1990 malah muncul posisi Boy Adam dengan kemungkinan kerugian US\$ 100 juta. Akhirnya, ketika transaksi valas Bank Duta ditutup, 15 Agustus 1990, total kerugian sudah mencapai US\$ 419,6 juta (Rp 780 milyar). Di antaranya US\$221 juta, berasal dari posisi Boy Adam. Selebihnya adalah kerugian yang diakibatkan oleh para dealer yang bermain atas perintah Dicky.

Kasus lainnya adalah kasus korupsi kerah putih yang terjadi di Tulungagung. Meskipun kasus ini tidak sebesar dan se-populer dengan kasus-kasus korupsi lainnya, namun perlu diungkapkan karena modus operandinya cukup menarik sebagai bahan pelajaran bagi penegak 
hukum untuk mewaspadai prilaku-prilaku banker atau petugas-petugas di dunia perbankan.

Korupsi ini dilakukan oleh Darmadi, adalah mantan Kaunit BRI (Kepala Unit Bank Rakyat Indonesia) Kecamatan Kedungwaru. Darmadi telah mendapat putusan dari Pengadian Negeri Temanggung dengan menjatuhkan hukuman 2 tahun penjara. Korupsi dilakukan Darmadi antara tahun 1991-1992 ketika dia menjabat Kepala Unit BRI Kecamatan Kedungwaru, Temanggung. Atas perbuatan itu, negara dirugikan lebih dari $R p 25$ juta dan ketika perkaranya terkuak, uang hasil korupsi itu sudah habis.

Korupsi itu, ungkap majelis hakim ${ }^{8}$, dilakukan dengan empat cara. Yakni, dengan cara kredit topengan (menggunkan nama nasabah lain), terutama nasabah yang sudah melunasi kredit lalu namanya dicatut, hingga seolah-olah kreditur tadi mengambil kredit kembali. Cara lain adalah menggunakan cara kredit tempilan, yaitu menambah nilai kredit dari para nasabahnya, sehingga nilai kredit yang cair lebih besar dari yang diminta kreditur. Dan kelebihannya masuk kantong Darmadi. Cara berikutnya adalah, Darmadi berani tidak membukukan uang setoran yang seharusnya dibukukan dan disetor ke kas, ternyata dimasukkan ke kantongnya dan hingga terungkap, jumlah uang yang dikantongi sekitar $\mathrm{Rp}$ 6,5 juta. Cara lainnya adalah, Darmadi juga berani tidak membayarkan uang IPTW (insentif pembayaran tepat waktu) kepada nasabah. Uang IPTW yang mestinya diberikan kepada nasabah, dikantongi sendiri. Salah seorang yang mencoba menelusuri, berhasil. Namun untuk membayar IPTW ini, Darmadi mengambil uang kas BRI.

Kasus yang terakhir dapat diajukan di sini adalah kasus korupsi yang mengakibatkan bobolnya uang negara di BAPINDO. Kasus ini sangat populer dengan nama "Kasus GKG" yang direktur utamanya adalah ET terlibat kredit macet sebesar Rp 1,3 triliun di Bank. BAPINDO tersebut.

Sampai tulisan ini disusun, kasus ini masih dalam proses pemeriksaan terhadap terdakwa ET. Tuduhan terhadap ET berlapis empat.
Yang terpenting, ia dituduh korupsi karena mendapatkan kredit dari BAPINDO tanpa menekan akad. ET didakwa melanggar UU No. 3 Tahun 1973 Pasal 1 ayat 1 sub a jo pasal 28 jo pasal 34 tentang tindak pidana korupsi dan. UU No. 5/PNPS Tahun 1959 pasal 2 tentang wewenang Jaksa Agung melakukan pemberatan ancaman hukuman terhadap tindak pidana yang membahayakan pelaksanaan perlengkapan sandang-pangan.

Unsur tuduhan korupsi, menurut Jaksa Lukman Bachmid ${ }^{9}$, terpenuhi. Unsur melawan hukum ada pada tindakan tidak ditekennya akad kredit sampai kasus itu meledak ke permukaan. Unsur memperkaya diri sendiri atau orang lain, jelas pada kucuran kredit yang mencapai $R p$ 962.396.105.113,-. Uang sebanyak itu, tidak semua dipakai untuk membiayai. proyek seperti dalam proposal. Dana yang diperoleh ET itu dianggap Jaksa membuat negara rugi. Karena itulah, ET dianggap melanggar pasal korupsi. Bagaimana kelanjutan kasus ini kita tunggu saja proses pengadilannya hingga selesai.

\section{Sebab-sebab Terjadinya Korupsi}

JIKA memperhatikan beberapa kasus di atas, maka jelas kita tidak akan mengatakan bahwa terjadinya korupsi itu disebabkan karena faktor kemiskinan. Memang benar, sebab keseluruhan kasus-kasus tersebut di atas memperlihatkan bahwa semua pelakunya tergolong orang-orang yang berada dan jauh dari kategori golongan orang-orang miskin, semuanya mempunyai kekayaan lebih dibanding dengan orang kebanyakan dan mempunyai status dan kedudukan sosial yang tinggi serta tentunya terpandang dalam masyarakat sekitarnya.

Meskipun demikian tidak pula mengingkari bahwa pada kasus-kasus korupsi lainnya, terutama yang dilakukan oleh para pegawai golongan menengah ke bawah, faktor kemiskinan ini dapat saja menjadi salah satu faktor terjadinya korupsi itu. Faktor kemiskinan ini misalnya adalah rendahnya pendapatan atau gaji yang diperoleh tidak sebanding dengan pengeluaran dalam memenuhi kebutuhan po- 
kok hidupnya. Mengenai masalah kurangnya gaji atau pendapatan pegawai negeri di Indonesia, oleh B. Soedarso dikatakan antara lain:

"Pada umumnya orang menghubungkan tumbuh suburnya dengan sebab yang paling gampang dihubungkan, misalnya kurang gaji pejabat- pejabat buruknya, ekonomi, mental pegawai yang kurang baik, administrasi dan management yang kacau yang menghasilkan adanya prosedur yang berliku-liku dan sebagainya." ${ }^{10 .}$

Masih diakui oleh B. Soedarso bahwa apa yang telah disebutkan tersebut bukanlah sebab yang mutlak, karena masih banyak faktor yang bekerja dan saling mempengaruhi satu sama lainnya. Namun demikian, menurut Andi Hamzah kurangnya gaji dan pendapatan pegawai negeri yang paling menonjol dalam arti merata dan meluasnya korupsi di Indonesia. ${ }^{11}$ Senada dengan itu adalah apa yang disebutkan oleh Schoorl yang mengatakan:

"Di Indonesia di bagian pertama tahun enam puluhan situasinya begitu merosot, sehingga untuk golongan-golongan besar dari pegawai gaji sebulan hanya sekedar cukup untuk makan dua minggu. Dapat dipahami, bahwa situasi demikian itu para pegawai terpaksa mencari penghasilan tambahan dan banyak di antara mereka mendapatkannya dengan meminta uang ekstra." ${ }^{12}$

Terlepas dari pendapat di atas, nampaknya saat sekarang ini sebab-sebab terjadinya korupsi, terutama korupsi kerah putih tidak lagi ditentukan oleh faktor tunggal melainkan disebabkan karena jalinan kerja-sama dan saling pengaruh-mempengaruhi dari berbagai macam faktor, yakni faktor internal dan faktor eksternal. Jalinan kerja-sama dan saling pengaruh antara faktor internal dengan faktor eksternal itulah mengakibatkan timbulnya korupsi.

Faktor internal yang dimaksudkan adalah sifat-sifat keadaan yang melekat pada diri seseorang, misalnya sifat serakah, sifat konsumtif, ketidak-jujuran, kontrol diri lemah (gampangan menerima hadiah atau toleransi yang berkelebihan), ketidak-tahuan, kebutaan dan lemahnya ketaatan serta kesalahan dalam memahami ajaran agama.

Berkaitan dengan faktor internal ini, Thucydides, Plato dan Aritoteles berpendapat bahwa kecenderungan pada keserakahan dan memikirkan kepentingan pribadi terutama di kalangan pimpinan adalah sebab utama korupsi ${ }^{13}$. Lain halnya pendapat Arifin Omar, mengatakan, tidak ada konsepsi mengenai pertanggung-jawaban kepada Tuhan atau kepada manusia. Dengan demikian benih korupsi telah ditaburkan ${ }^{14}$.

Sementara faktor eksternal yang dimaksud adalah keadaan di luar diri seseorang, misalnya manajemen yang kurang baik dan kontrol yang kurang efektif dan efisien, pertumbuhan ekonomi dan pendapatan masyarakat rendah, pameran kemewahan barang-barang konsumtif secara berkelebihan, kelemahan pengajaranpengajaran serta pengamalan-pengamalan agama dan etika, lemahnya sistem pendidikan, proses hukum tidak efektif dan tiadanya pidana yang keras. Dan lain sebagainya.

\section{Alternatif Pencegahan Korupsi}

PENCEGAHAN terhadap korupsi kerah putih adalah merupakan pekerjaan besar dan sangat sulit, mengingat pelaku korupsi justru dilakukan oleh orang-orang yang mempunyai kedudukan/kewenangan publik, di mana dengan kedudukannya tersebut, maka si pelaku dapat dipastikan merupakan pribadi yang mempunyai latar-belakang pendidikan yang relatif cukup dan berasal dari lapisan sosial menengah ke atas. Bahkan tidak menutup kemungkinan mereka mempunyai kekuatan lobby di kalangan atas untuk menghindarkan diri dari tuntutan hukuman.

Usaha memberantas korupsi sudah lama dilakukan, bahkan sejak orde lama usaha ini sudah dimulai terbukti dengan adanya peraturan-peraturan yang telah dikeluarkan, seperti dikeluarkannya UU 24 Prp Tahun 1960 yang kemudian karena undang-undang ini 
dianggap tidak efektif akhirnya dicabut dan diganti dengan UÚ No. 3 Tahun 1971.

Ada yang berpendapat bahwa memberantas korupsi adalah tidak mungkin dan jangan bermimpi akan dapat memberantas korupsi itu. Pendapat ini ada benarnya, sebab usaha apa pun yang telah dilakukan, nampaknya tidak mampu mengurangi apalagi menghilangkan sama sekali korupsi itu, kenyataannya korupsi masih tetap ada bahkan cenderung meningkat.

Memang kita tidak berusaha memberantas korupsi sampai tuntas ke akar-akarnya. Yang dapat dilakukan adalah mencegah jangan sampai penyakit korupsi itu semakin merajalela. Berkurangnya angka kejahatan korupsi adalah sasaran utama dari upaya pencegahan. Persoalannya adalah alternatif apa yang dapat dilakukan untuk mencegah kejahatan korupsi itu?

Bila memperhatikan faktor penyebab korupsi sebagaimana yang telah dikemukakan di muka, maka usaha pencegahannya tidak dapat dilakukan hanya dengan mengandalkan hukum pidana/penal melainkan harus disertai dengan usaha-usaha di luar hukum pidana/non-penal. Hal ini dapat dipahami karena masalah korupsi bukan lagi sekedar masalah hukum tapi sudah menjadi masalah sosial yang kompleks. Terlebih lagi bila memperhatikan faktor-faktor penyebabnya itu, maka semakin yakin bahwa pencegahan korupsi selain dengan jalur hukum pidana, harus pula dilakukan dengan melibatkan dan memfungsikan kegiatan-kegiatan sosial serta mendaya-gunakan setiap potensi positif masyarakat yang ada.

Pencegahan korupsi melalui jalur hukum pidana, berarti menempatkan hukum pidana sebagai panglima yang secara konsekuen harus difungsikan tanpa ada pengurangan sedikit pun dari setiap informasi-informasi atau statemen yang ada pada setiap pasal-pasalnya. Dalam hal demikian, maka dibutuhkan suatu formulasi yuridis dari setiap perumusan hukum pidana yang mengimplementasikan nilai-nilai yang diakui dan diterima serta mampu menjadi perisai dan penangkal penyakit korupsi.

Selain membutuhkan suatu formulasi yuridis dari hukum pidana, dibutuhkan pula pelak- sanaan dan penerapan dari setiap :formulasi yuridis tersebut oleh petugas-petugas bijak, berdedikasi dan penuh tanggung-jawab. Pelaksanaan dan penerapannya adalah tahapantahapan yang turut menentukan keberhasilan pencegahan korupsi. Sebab betapapun baiknya formulasi yuridis dari hukum pidana itu tanpa diimbangi oleh pelaksanaan dan penerapan yang baik dan konsekuen, niscaya tidak akan menghasilkan apa-apa kecuali kekecewaan belaka.

Undang-undang Nomor 3 Tahun 1971 tentang Pemberantasan Tindak Pidana Korupsi adalah satu produk lembaga legislatif yang diharapkan menjadi panglima untuk memberantas kegiatan korupsi. Undang-undang ini menyempurnakan Undang-undang sebelumnya dan sekaligus mencabutnya karena dianggap kurang mampu mengikuti perkembangan zaman. Jika memperhatikan formulasi mengenai delik- delik dan ancaman pidana yang terdapat dalam Undang-undang ini dapat dikatakan baik dan progresif. Tapi kenapa Undangundang ini dengan mudah diterobos oleh pelaku-pelaku korupsi? Barangkali kesalahannya adalah pada pelaksanaan dan penerapannya yang tidak konsekuen mengikuti apa yang menjadi keinginan dalam setiap rumusannya. Kalau memang demikian adanya, maka pelaksanaan dan penerapannya itu perlu mendapat perhatian yang serius.

Satu hal perlu mendapat perhatian dan pertimbangan adalah "pembuktian terbalik". Konon, di negara tetangga kita Malaysia, tingkat kejahatan korupsi dapat ditekan karena menerapkan "pembuktian terbalik" ini. Beda halnya dengan negara kita, Undang-undang Korupsi kita belum ada dan tidak melaksanakan sistem pembuktian terbalik. Sekedar mencontoh negara-negara yang berhasil menerapkan sistem pembuktikan terbalik, maka sudah saatnya mempertimbangkan penggunaan sistem pembuktian terbalik ini. Ada yang menilai bahwa prinsip tersebut bertentangan dengan asas presumption of innocence (praduga tak bersalah) ${ }^{15}$. Tanpa mengabaikan pendapat tersebut prinsip "pembuktian terbalik" tetap diperlukan mengingat tingkat dan 
kualitas kejahatan korupsi sudah membahayakan.

Sistem pembuktian terbalik akan memudahkan jaksa dalam menuntut orang-orang yang dicurigai melakukan korupsi serta mengurangi beban dalam pembuktian karena beban pembuktian tidak lagi dibebankan kepada Jaksa Penuntut Umum, melainkan dibebankan kepada terdakwa. Artinya, terdakwalah yang akan membuktikan bahwa dirinya tidak melakukan korupsi dengan menerangkan sumbersumber dari harta kekayaan yang ia miliki.

Meskipun terdapat kemudahan bagi Jaksa dalam proses pembuktian ini, namun tetap dibutuhkan keberanian moril untuk menuntut pejabat/pegawai atau siapa saja yang dicurigai dan potensial menjadi pelaku korupsi, tanpa keberanian tidak ada artinya pembuktian terbalik itu. Memang terdapat masalah bagi Jaksa Penuntut Umum jika yang dituntut ke Pengadilan itu mampu membuktikan sumbersumber kekayaannya yang sah dan bukan hasil korupsi. Apakah dengan demikian Jaksa Penuntut Umum harus dituntut balik karena telah salah sangka dan salah mendakwa? Untuk tetap menjamin keberanian itu, barangkali perlu perlindungan hukum, sehingga kejadian itu tidak perlu mengakibatkan Jaksa dituntut balik.

Penggunaan hukum pidana tersebut di atas belumlah menjamin mengikisnya korupsi tanpa diikuti dengan usaha-usaha yang sifatnya non-yuridis. Usaha-usaha ini agar efektif tentunya harus disesuaikan dengan faktor-faktor yang menyebabkan terjadinya korupsi. Oleh karena itu perhatian kita adalah berusaha untuk menghindari dan tidak lagi menempatkan individu-individu yang memiliki sifatsifat serakah, rakus, ketidak-jujuran pada posisi-posisi vital dalam suatu birokrasi pemerintahan.

Usaha mencegah korupsi harus dimulai dengan menekankan keharusan dan wajib adanya individu-individu yang menduduki posisi-posisi vital dan penting tidak saja dalam birokrasi pemerintahan tapi pada semua posisi-posisi penting yang ada dalam masyarakat. Individu-individu ini adalah individu-individu yang harus memiliki sifat-sifat jujur, prinsip-prinsip yang tinggi, dan penuh pengabdian untuk mengikis korupsi. Upaya tersebut harus mencari cara dan sarana menciptakan individu-individu yang dimaksudkan. Lebih daripada itu, upaya tersebut harus berhasil menanamkan rasa enggan berkorupsi di kalangan individu yang menduduki posisi-posisi vital . (para pemegang kekuasaan).

Terhadap faktor individu ini, menarik apa yang dikemukakan oleh Syed Hussein Alatas, bahwa ${ }^{16}$ :

Dalam konfigurasi faktor-faktor ini, kaliber moral individu yang bersangkutan menentukan. Sama halnya, perubahanperubahan struktural dan legal dalam administrasi pemerintahan yang dirancang untuk memberantas korupsi tidak akan berhasil, jika tidak ada sejumlah individu-individu yang punya prinsip tinggi yang menduduki posisi-posisi kunci dan vital untuk keberhasilan usaha itu.

Untuk lebih mendukung upaya tersebut maka pemahaman, penghayatan dan pengamalan agama harus semakin digalakkan dan ditingkatkan melalui keluarga, sekolah, tempattempat ibadah, lingkungan kerja. Kegiatan ini harus berkesinambungan, bukanka sporadis dan temporer melainkan terus-menerus, di mana saja dan kapan saja. Sosialisasi nilai-nilai keagamaan yang meresap mendalam pada setiap individu-individu, niscaya akan mampu menghasilkan individu-individu yang bermoral, berperilaku jujur, penuh pengabdian dan mempunyai prinsip tinggi yang siap menentang dan mencegah segala kemungkaran, meskipun pahit adanya.

Usaha lain yang dapat dilakukan adalah memperbaiki tatanan perekonomian, birokrasi dan management yang mampu mendukung pemerataan hasil-hasil pembangunan sehingga kesejahteraan pegawai dan seluruh rakyat semakin meningkat dan membaik. Birokrasi yang berbelit-belit dan melelahkan sedapat mungkin dihindari, diganti dengan birokrasi simpel dan sistemik yang dengan mudah 
menyelesaikan dan menghasilkan berbagai macam urusan. Hubungan-hubungan birokrat hendaknya diperjelas dengan batasan-batasan kewenangan yang mengikat. Interpensi pejabat dari instansi lain baik secara kelembagaan maupun individual yang dapat mengganggu bahkan merusak tatanan dan kebijakan manajemen hendaknya dihindari dan ditutup rapat-rapat.

Alternatif terakhir yang dapat dikemukakan adalah menciptakan iklim anti korupsi baik di tingkat pemerintahan maupun di kalangan masyarakat luas. Issu tentang anti korupsi tetap digalakkan dan terus-menerus harus disebarkan secara luas. Demikian pula kebusukan dan bahaya-bahaya korupsi perlu terus-menerus ditunjukkan kepada masyarakat, sehingga muncul pula sikap jijik dan semangat penolakan terhadap korupsi. Mudah-mudahan dengan demikian korupsi dapat dicegah. Amin.

Rusli Muhammad, SH, MH, adalah staf pengajar FH UII. Menyelesaikan jenjang S-I pada Fak. Hukum UII, serta jenjang S-2 pada Universitas Indonesia.

\section{Catatan Kaki:}

1. Muladi, : "Politik Kriminal Dalam Rangka Penanggulangan Tindak Pidana Perbankan" (Makalah disajikan pada Seminar Tindak Pidana di Bidang Perbankan di UNDIP pada tanggal (1-12 Juni 1990).

2. J.E. Sahetapy: "Kejahatan Korporasi Ditinjau dari Sudut Kriminologi" (Makalah disampaikan pada Seminar Kejahatan Korporasi di UNDIP Semarang tanggal 23-24 Nopember 1989).

3. Mukhtar Lubis: "Etika Pegawai Negeri", (Jakarta, Penerbit: Yayasan Obor, 1977) hal. 4.

4. Harian Kompas tanggal 15 Agustus 1980.

5. Moeljatno, :"Azas-azas Hukum Pidana". (Yogyakarta: Penerbit, Liberty) hal 185.

6. Leden Marpaung, "Tindak Pidana Korupsi Masalah dan Pemecahannya". (Jakarta, Penerbit: Sinar Grafika, 1992) hal. 81.

7. Dikutip dari Majalah Tempo tanggal 6 Juli 1991.

8. Harian Jawa Pos tanggal 5 Mei 1994

9. Forum Keadilan Nomor 3 Tahun III, 26 Mei 1994.
10. B. Soedarso, "Korupsi di Indonesia" (Jakarta, Penerbit Bhratara, 1969) hal. 10.

11. Andi Hamzah, "Korupsi di Indonesia" (Jakarta, Penerbit, PT Gramedia Pustaka Utama, 1991) hal. 17.

12. J.W. Schoorl, "Modemisasi", terjemahan R.G. Soekadijo. (Jakarta, Penerbit PT Gramedia) hal. 180.

13. Dikutip dari buku "Seri Wawasan Korupśi" (Jakarta, Penerbit Lembaga Studi Pembangunan, 1986) hal. 29.

14. Ibid., hal. 38.

15. Cipto Soeroso, "Pemberantasan Tindak Pidana dan Komplikasi yang Menyertainya" (Dalam Majalah Masalah-masalah Hukum. Fakultas Hukum UNDIP, No. 4-1990) hal. 6.

17. Syed Hussein Alatas, "Sosiologi Korupsi" (Jakarta. Penerbit LP3ES, 1986) hal. 63.

\section{Daftar Pustaka}

1. Alatas, Syed Huseen: "Sosiologi Korupsi" (Jakarta, Penerbit: LP3ES, 1986).

2. Hamzah, Andi: "Korupsi di Indonesia" (Jakarta, Penerbit: PT Gramedia, 1991).

3. Lubis, Mukhtar:- "Etika Pegawai Negeri" (Jakarta, Penerbit: Yayasan Obor, 1977).

4. Marpaung, Leden: "Tindak Pidana Korupsi Masalah dan Pemecahannya" (Jakarta, Penerbit: Sinar Grafika, 1992).

5. Moeljatno: "Asas-asas Hukum Pidana" (Yogyakarta, Penerbit: Liberty, tanpa tahun).

6. Muladi: "Politik Kriminal dalam Rangka Penanggulangan Tindak Pidana Perbankan" (Makalah disajikan pada Seminar Tindak Pidana di Bidang Perbankan di UNDIP).

7. Sahetapy, J.E.: "Kejahatan Korporasi Ditinjau dari Sudut Kriminologi" (Makalah disajikan pada Seminar Kejahatan Korporasi di UNDIP).

8. Scoorl, J.W.: "Modernisasi", terjemahan, Soekadijo R.G. (Jakarta, Penerbit: PT Gramedia, 1980).

9. Soedarso, B.: "Korupsi di Indonesia" (Jakarta, Penerbit: Bhratara, 1969).

10. Soeroso, Cipto: "Pemberantasan Tindak Pidana Korupsi dan Komplikasi yang Menyertainya" (Makalah dalam Majalah, Masalah- masalah Hukum, Penerbit FH UNDIP No. 4. 1990).

11. Seri Wawasan Korupsi (Jakarta, Penerbit Lembaga Studi Pembangunan, 1986).

12. Harian Kompas tanggal 14 Agustus 1980.

13. Harian Jawa Pos tanggal 5 Mei 1994.

14. Majalah Tempo tanggal 6 Juli 1991.

15. Forum Keadilan No. 3 Tahun III tanggal 26 Mei 1994 